\title{
On EFL Learners' Awareness of Their Writing Abilities and Preferences
}

\author{
Sundus Ziad AlKadi ${ }^{1, *} \&$ Abeer Ahmed Madini ${ }^{1}$ \\ ${ }^{1}$ English Language Institute, King Abdulaziz University, Jeddah, Saudi Arabia \\ *Corresponding author: English Language Institute, King Abdulaziz University, Jeddah, \\ Saudi Arabia. E-mail: sundus.alkadi1111@gmail.com
}

Received: May 13, 2019 Accepted: June 2, 2018 Published: June 7, 2019

doi:10.5296/ije.v11i2.14775 URL: https://doi.org/10.5296/ije.v11i2.14775

\begin{abstract}
This study explores EFL learners' self-awareness of their writing abilities and preferences in writing genres in foundation year writing course. It was conducted at the University of Business and Technology (UBT), in Saudi Arabia. A sample of 73 female intermediate level learners participated in the study, the aim of which was to highlight learners' self-awareness of their writing abilities and preferences in writing. The study used a survey as a data instrument. The writing preferences survey acted as a vote for the preferred writing genre, and a visual representation of the learners' self-awareness of their writing strength and weakness points. The results showed that the majority of the learners preferred the narrative and opinion genres of writing. The results also showed the significance of highlighting the learners' self-awareness in their writing abilities to make them become self-regulated learners.
\end{abstract}

Keywords: Writing Genre, Writing Preferences, Self-regulation 


\section{MlMacrothink}

\section{Introduction}

Teaching writing to foreign language learners is an inception in itself, and challenging but it could be enjoyable if EFL teachers understand their learners' needs and preferences. With new technology and globalization, L2 learners' preferences in learning within a particular context, as in Saudi higher education, should be highlighted and taken into consideration. In the current study, learners' preferences in writing is highlighted in terms of self-regulation, and genre, i.e., narrative, argumentative, opinion, process, and so on. In the current paper, recognizing the learners' self-regulation and preferences in writing is the core of this investigation. The writing preferences survey is the tool which is used to approach the learners' self-awareness of their strength and weakness points on one hand, and their preferences in writing on the other hand.

\section{Rationale and Aim}

The study under investigation adds to the existing literature regarding preferences in writing in the Saudi context and develops its pedagogies in L2 writing following the recently used approaches to teaching writing, especially when it comes to Computer-Assisted Language Learning (CALL) and collaboration. The purpose of the current study was to see L2 writers' writing preferences through survey and to examine the learners' trust on the effectiveness of the recent technological teaching composition approaches. The study tackles many factors, namely: the strong connection between reading and writing, the importance of collaborative writing in the second language writing community, genre, error recognition, and the new technology and its influence on the Saudi L2 writers to help them in writing.

\section{Research Questions}

The study is guided by the following questions:

1. What writing genre do L2 novice writers prefer?

2. Were those writers aware of the strength points and the weakness points of themselves?

\section{Literature Review}

\subsection{EFL Learning and Writing}

Learning to write can be viewed from four different perspectives, namely behaviorist, innatist, cognitivist, and interactionist (Tseng, 2009). Within these scopes, the differences between native and non-native writers might be seen in their written work (Patten \& Benati, 2010). However, it is debatable whether L2 writers can become native-like writers. It is not necessary to judge the quality of native writers and L2 writers' written work, as there is no difference between their productions except for competence and critical thinking (Janopoulos, 1992; Doolan, 2017; Qu, 2017). Plenty of subprocess models are available to describe how 
L2 writers produce written work. Zimmermann (1999) overviewed and modified many significant writing models, especially the Hayes and Flower (1980) Model; he emphasizes the word 'formulating' instead of 'translating', and focuses on the production of individual sentences (pp. 75-85). In the L2 writing subprocess, it takes more time in the pre-writing stage to formulate a text (Zimmermann, 1999). However, it is important to consider L2 writers' differences and the variety of their learning styles by running good preferences surveys. There are three processes of writing derived from Kellogg's Model, namely: "lexical retrieval (words), syntactic encoding (sentences), and cohesiveness (style), so individual differences are involved in each stage" (Kormos, 2012, pp. 391, 392). However, it is necessary to run Preferences Questionnaires to address learners' needs with regards to writing (Chandler, 2003; Ferris \& Hedgcock, 2014; Ferris, 2011; Leijten, Waes, \& Ransdell, 2010).

Deciding on preferring accuracy over fluency and vice versa remains debatable. Accuracy is defined as how the speaker of a second language pays attention to grammar and pronunciation, whereas fluency is the systematic use of language which is produced naturally (Alsagoff, 2018). Another important distinction to be discussed while assessing writing is the difference between performance and competence. Moreover, the 'accuracy theory' is the extent that the learner follows linguistic rules of a second language, and it usually regards any other feature that deviates from the faculty of language as 'errors', whereas the 'fluency theory' refers to the flexibility of meaningful language expression (Bui \& Skehan, 2018). According to Wetzorke (2005), deviances are identified into: 'mistakes' that are related to performance, and the learners are aware of them, 'errors' that are related to competence, and the learners are unaware of them, and 'slips' that are related to sub-mistakes as seen in pen lapse or carelessness of the writers.

Performance is the contextual use of a language in a real-life situation, whereas competence is the knowledge of the cognitive use of the language. Recently, the most used word to describe competence is the 'communicative competence' that includes grammatical competence and other aspects of language, e.g., sociolinguistic, pragmatic, and many others. Turning now to the difference between linguistic competence and communicative competence, the former refers to the systematic knowledge of language forms whereas the latter refers to the use of this systematic knowledge in a context via writing and speaking as well (Hymes, 1966). For Hymes, competence is a combination of both linguistic and communicative features of a language, i.e., language is a construct that runs in a social manner. Therefore, the present paper highlights the learners' self-awareness of their performance in writing.

Moving on now to consider tabbing into metacognition, which is paramount before designing a writing task. According to Zhang and Zhang (2018), learners' metacognitive knowledge can be classified into three main types, namely: person knowledge (self-awareness), task knowledge (nature of task), and strategy knowledge (cognitive and sociocognitive strategies). The goals behind highlighting the importance of metacognitive knowledge in writing tasks are to foster learner autonomy and raise L2 learners' awareness of knowledge types.

One of the most critical hypotheses in the field of applied linguistics that concerns literacy 
skills is the 'comprehensible input' by Stephen Krashen that he came up with in the late 1980s naming it (Lee, 2018). The two keywords to discuss it are 'understanding messages'. Based on previous theoretical literature reviews, it is suggested that the input must be comprehensible and makes form-meanings connections to allow learners to notice the form and comprehend the meaning of that form (Hernandez, 2018). Input flooding is effective when it targets 'lexico-grammatical features' which indicate adding meaning to form. In other words, to support this influential hypothesis is what Schmidt came up with: 'the noticing hypothesis' to make the input more conscious-raising to foster L2 learning process when noticing form and meaning and their interaction within the input (Leow, 2018). Therefore, learning writing in a second language could be a reflection of many SLA theories and models depending on the context, EFL teachers, and the curriculum.

\subsection{L2 Writing Integrated with Reading and Comprehensible Input}

Reading is a paramount aspect that is connected to L2 writing. A likely explanation occurs in texts that are assigned to be read using both top-down and bottom-up approaches with regards to recognition of the grammatical and lexical features along with content, reading purposes, genre, and other organizational features (David \& De Hoyos, 2018). It is almost certain that second language readers' benefit from both top-down and bottom-up reading approaches. In light of reading and its connection to writing, the reading text is a form of a comprehensible input that is probably should be simplified for the L2 learners in ways that curriculum designers focus on, particularly, grammatical and lexical features (Crossley, 2018). In short, simplification of input should aim at making the input comprehensible and accessible to the L2 readers with regards to linguistic and content information. The good preferences survey must tab into the reading-writing connection.

One of the most common problems in L2 reading is the transfer of ability. First language reading affects second language reading, i.e., learners who are active readers in their first language are capable of transferring reading strategies in L2 (David \& McGovern, 2018). In other words, literacy skills of reading and writing should be enhanced and fostered in L1 before L2, which might be a gap for Arab L2 learners who are beginners in reading and writing. Therefore, building a culture of reading within the context is of vital importance. A culture of reading can be built when the L2 learner is ready and sees reading as a valuable activity to enjoy (Recinos, 2018). However, L2 readers in the Arab context may be ignorant of both content and cultural knowledge of other societies and might have preferences in reading texts and will probably be facing difficulties in reading and writing. All these factors will be reflected in their texts as outputs (Grabe \& Jiang, 2018).

With regards to reading texts as a comprehensible form of input, previous studies have found that even after eight to ten years of second language exposure, L2 learners continue make grammatical errors despite their native-like comprehension (Ahmed \& Han, 2018). This gives rise to the question of whether to give an argument that highlights the importance of reading to write: 'why do language teachers want their learners to read before writing?' According to Mokhtari (2018), prior knowledge is the crucial factor of the other four types of knowledge, namely: "general knowledge, specific knowledge, knowledge of language (forms and 
functions), and knowledge of how information is organized". It also helps in making inferences and drawing conclusions to prepare for producing texts (Mokhtari, 2018). Therefore, the present study focuses on reading before writing to help the learners produce their own texts.

Another aspect that is integrated with literacy skills is vocabulary. In general terms, there is a strong correlation between reading comprehension and vocabulary since the reading activity is a way of acquiring new vocabulary (Erten, 2018) (in Nation, 2001). In light of this, gaining vocabulary through reading helps to use them it writing. Integrating vocabulary with a writing topic can cause problems in writing production, i.e., learners should have sufficient vocabulary knowledge to use it in writing (Coxhead, 2018). As a result, vocabulary use promotion in writing can be by setting a reading program from different sources and with interesting topics that are context-related and at the right level of the readers along with allowing them to write and speak about what they have read. Strategies to enhance the core goal of reading might involve writing, grammar, and vocabulary (Anderson, 2018) (see Figure 1) below.

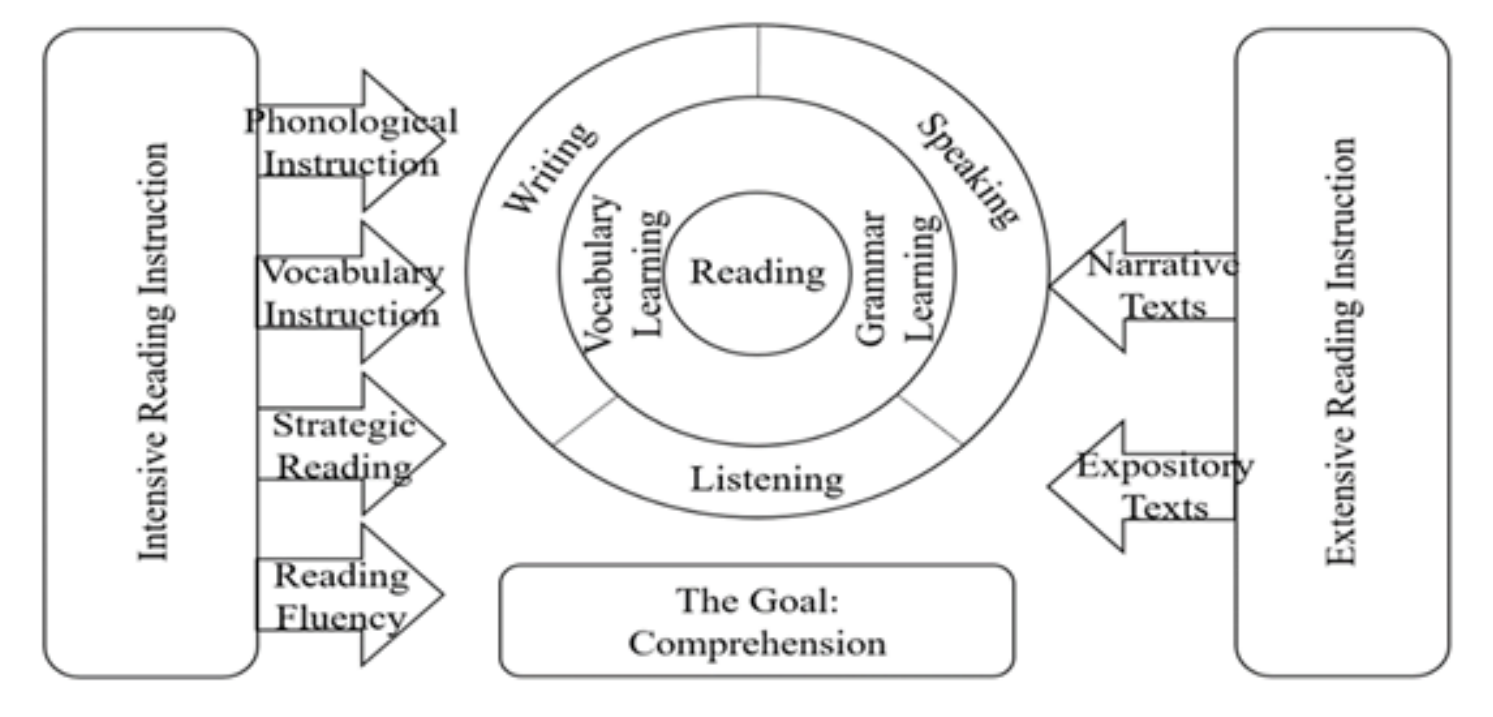

Figure 1. "A pedagogical model for reading instruction" (based on Anderson, 2018, p. 2213)

Furthermore, highlighting the purpose of reading is significant to enhance comprehension of readers (De Hoyos \& David, 2018), so setting a purpose for writing is also essential to foster L2 writers' abilities to produce texts.

The genre is another important inclusive aspect in the mindset of L2 writing. It is defined as groups of rhetorical goals that share similar features, i.e., vocabulary, tense, and voice (Hyland, 2018). A well-known example of the genre is 'narration' which has particular features such as imagination and realism, using details of people and places by using the descriptive language (Olson, Scarcella, \& Matuchniak, 2018). It is necessary to clarify what the advantages of genre-based writing are: "explicit, systematic, needs-based, supportive and 
empowering, critical, and awareness-raising" (Hyland, 2004).

As discussed above, L2 writing is never taught alone, but instead, it has to be connected to other skills, especially reading. The reading-writing connection improves the writing skills on the subprocess level and the cognition level, that is involved in planning, and synthesizing; this exists when teachers teach the reading skill explicitly and balance it in overall multiple literacy practices (Lee \& Schallert, 2015; Ferris \& Hedgcock, 2014). Krashen (in Hirvela, 2004; Warschauer, 1997) states that "in the competence-performance theory, it is a must to explicit teaching to activate the subconscious acquisition of meaning creation" (Krashen, 1984) which is the reading-to-write approach to improve writing. One of the most critical roles of the reading-to-write approach is creating Genre awareness. A Genre is characterized in the aspects of explicitness, integrativeness, and being competency-focused (Hyland, 2004). In the present study, a preferred reading genre by the L2 learners to produce texts is employed.

The communicative approach is the big circle of the integrative approach of language teaching, which is currently being used in university contexts, and considered to be one of the most useful pedagogies in collaborative writing. The communicative approach is not just limited on communication between learners, but indeed, it indicates the integration between the text and its elements including genre and lexicogrammar. It is suggested that writing test makers should include a clear input of instructions in order to elicit the possible output from the test takers, so reading interferes with the writing ability to be assessed in a compelling way (Hughes, 2003). Hughes (2003) also continues to employ the communicative approach in assessing the grammatical knowledge of writers. The shift of the communicative language approach has highlighted meaning-making rather than accuracy in order to promote the communicative language competence that includes both linguistic and sociolinguistic competence ( $\mathrm{Li} \&$ Zhou, 2018). In this entry, authentic materials act as tools of the communicative approach of language teaching, which is used to supply the textbooks to promote learners' communicative competence. Classic examples of authentic materials are magazines, newspapers, and many others, but they are mainly replaced nowadays with authentic digital materials, such as iBooks, and social media applications on portable devices. Modern language classrooms integrate the communicative competence in order to develop the learning of the four skills of English language that serves real-life goals, especially the ones related to collaboration (Ruschoff, 2018). Indeed, authentic materials that are influenced by the communicative approach modify the comprehensible input and promotes vocabulary acquisition of L2 learners. The good preferences in writing survey must have an exposure to authentic materials.

Teaching language skills and elements in an isolated manner is criticized, especially grammar and vocabulary that are taught in decontextualized texts (Taylor, Despagne, \& Faez, 2018). In turn, language awareness has emphasized the importance of the communicative language approach in which it encourages skills integration as seen in grammar and vocabulary that are integrated with reading and writing. This incident can be seen in case of the reading and writing connections since that they are both dependent on similar knowledge representations, such as content knowledge, meta-knowledge, textual knowledge, and procedural knowledge 
(Zhang, 2018). The reading-to-write approach or reading-based writing is involved in integrated-skills assessment which has been used in writing tasks at the University of Michigan (MSU) since 2009 (Gebril, 2018). This type of task is encouraged to allow learners to form ideas and shape opinions on one hand, and to use texts as sources for evidence and language aids that consist of form and meaning on the other. In other words, reading texts as models and comprehensible inputs to produce a written output. However, it is suggested that teaching grammar in isolation would be helpful to reduce confusion and errors, but it should be followed by teaching it using the communicative approach (Valeo, 2018).

\subsection{Gaps}

The study fills gaps in the literature of L2 writing globally and locally. Globally, previous studies have focused on investigating reading online versus paper-based, but writing preferences of the learners were neglected. According to Huang (2014), technology plays a crucial role in increasing reading comprehension among learners in general. The limitation of this previous study was the need of implementing preferences surveys on writing.

In the Saudi context, studies were vital to address gaps in the literature of L2 writing. A study was conducted in Saudi Arabia to investigate the effectiveness of exchanging emails and reading-writing connection on college students to see their literacy development. According to Zaid (2011), the quasi-computer-based study explored the effects of e-mail genre on improving both reading and writing of college students. His study found that learners' attitudes towards English were positive because of collaboration. Although the study connects writing to reading, genre, and collaboration; it only focused on one genre (e-mails writing). In other words, it did not give the participants a chance to express their self-awareness and preferences in the writing genre.

In light of studies conducted in the Saudi context, there was no study in the literature that emphasized the significance of the writers' self-awareness and preferences in their writing abilities. Therefore, the current study fills the gap in the literature of L2 writing by creating genre awareness through learners' preferences.

\section{Methodology}

\subsection{Theoretical Framework}

The study epistemologically modeled on the Zone of Proximal Development (ZPD) of Vygotsky (1978). In other words, the participants who were involved in the present study were supposed to be aware of their writing abilities and disabilities by the preferences survey, so they can rely on themselves and be self-regulated writers.

\subsection{Participants}

The research stratified sample was based on 73 undergraduate female students, aged between 18 and 23 years old, of the foundation year at the University of Business and Technology (UBT). The learners involved in the present study were placed by the institutions in levels 


\section{Macrothink}

five and six, and are characterized as upper-intermediate learners according to the Common European Framework (CEFR). The same survey was sent separately to eight classrooms, in order to get more reliable results.

\subsection{Research Design}

This is a pure quantitative research that used a survey. Prior to the present exploratory study, writing preferences survey was adapted from (Ferris \& Hedgcock, Teaching L2 Composition Purpose, Process, and Practice, 2014) (in Appendix 1). The contents of the survey determined the strength and preferences of the learners in terms of writing, and the questions covers the following points:

1. I think I am successful academic writer in my home language.

2. I think I am a successful writer of academic English.

3. In my writing assignments, I effectively use source material (e.g., print and digital books, articles, news reports, editorials, etc.).

4. One of my strengths as a writer of English is producing interesting ideas.

5. I am skilled at organizing ideas and expressing them clearly to my reader.

6. I have learned how to write academic texts mostly through reading.

7. When I work on an assignment, I work almost entirely on a computer.

8. I use good word-processing and Internet skills when I work on assignments.

9. I rearrange my ideas a lot when I plan a writing assignment.

10. When I revise a paper or a draft, I often make a lot of changes.

11. As I revise an assignment, I like to add new material.

12. When I plan, write, and revise an assignment, I think carefully about what my reader expects from my text.

13. Before I revise an assignment, I ask someone to give me comments and advice.

14. My academic assignments usually open with a clear purpose, argument, or thesis.

15. In my academic assignments, I try to include examples and sources to support my points.

16. I try to connect paragraphs to my main ideas or arguments in my academic assignments.

17. When I turn in assignments, they contain few grammatical errors.

18. My assignments show that I have a strong command of English vocabulary.

19. My assignments usually contain minor spelling and punctuation errors.

20. I am confident about using references, quotations, and footnotes in my assignments.

21. I know how to organize and format a bibliography or list of references. 
22. I learn a lot from the comments and corrections that my instructors write on my assignments.

23. I enjoy sharing my writing with other students and learn from reading other students' writing.

24. After getting instructor feedback on my writing, I learn things that I can apply to future writing tasks.

25. I prefer to interact with my instructor and get feedback digitally, rather than on paper or in person.

26. What genre do you prefer to write?

The surveys were sent to four teachers who teach levels five and six, as each teacher teaches two sections, because the UBT have small classes, and each class has a capacity of 10 to 15 students. The surveys were sent via Google Forms. All the students have responded to all of the 26 items of the questionnaire under the supervision of their teachers. The teachers were asked to make the students aware that ( $1=$ Strongly agree $)$, and ( $6=$ Strongly disagree $)$. The aim of the writing preferences survey was to determine the learners' preferences in writing on one hand, and to see the learners' awareness of their errors on the other hand.

A question of genre writing preference was added to give the learners the opportunity of selecting a genre they would prefer to write about. The survey was translated into Arabic to get more reliable responses from the learners because their first language is Arabic. The survey was piloted, and the learners responded to all of the 26 questions (See Appendices 1 and 2). The elements of the survey and their responses were run and analyzed by the SPSS software. The Cronbach alpha reliability test was applied to the survey and resulted in the value (0.895), which indicated that the survey items are highly reliable, because the reliability value was more than (0.75). Therefore, the survey is said to be reliable, and its scale has an excellent internal consistency value, with Cronbach alpha coefficients of (0.895) (See Table 1 below).

Table 1. The Reliability of the Preferences Survey after Piloting

\begin{tabular}{cc}
\hline \multicolumn{2}{c}{ Reliability Statistics } \\
\hline Cronbach's Alpha & N of Items \\
.895 & 25 \\
\hline
\end{tabular}

\section{Data Analysis and Results}

Referring to the UBT writing curriculum, the last question of genre preferences in writing was modified by adding more choices, namely opinion, cause and effect, classification, process, and graph description. The participants responded to all the 26 questions, but the researcher left the last question to highlight the preferred genre by the learners. The survey is 


\section{Macrothink}

distributed to four groups of the participants according to their levels.

The following figures and tables describe the four groups' responses to the preferences surveys. Group 1 (see Figure. 2) and Group 2 (see Figure. 3) are described statistically. Likewise, Group 3 (see Figure. 4) and Group 4 (see Figure. 5) are described statistically.

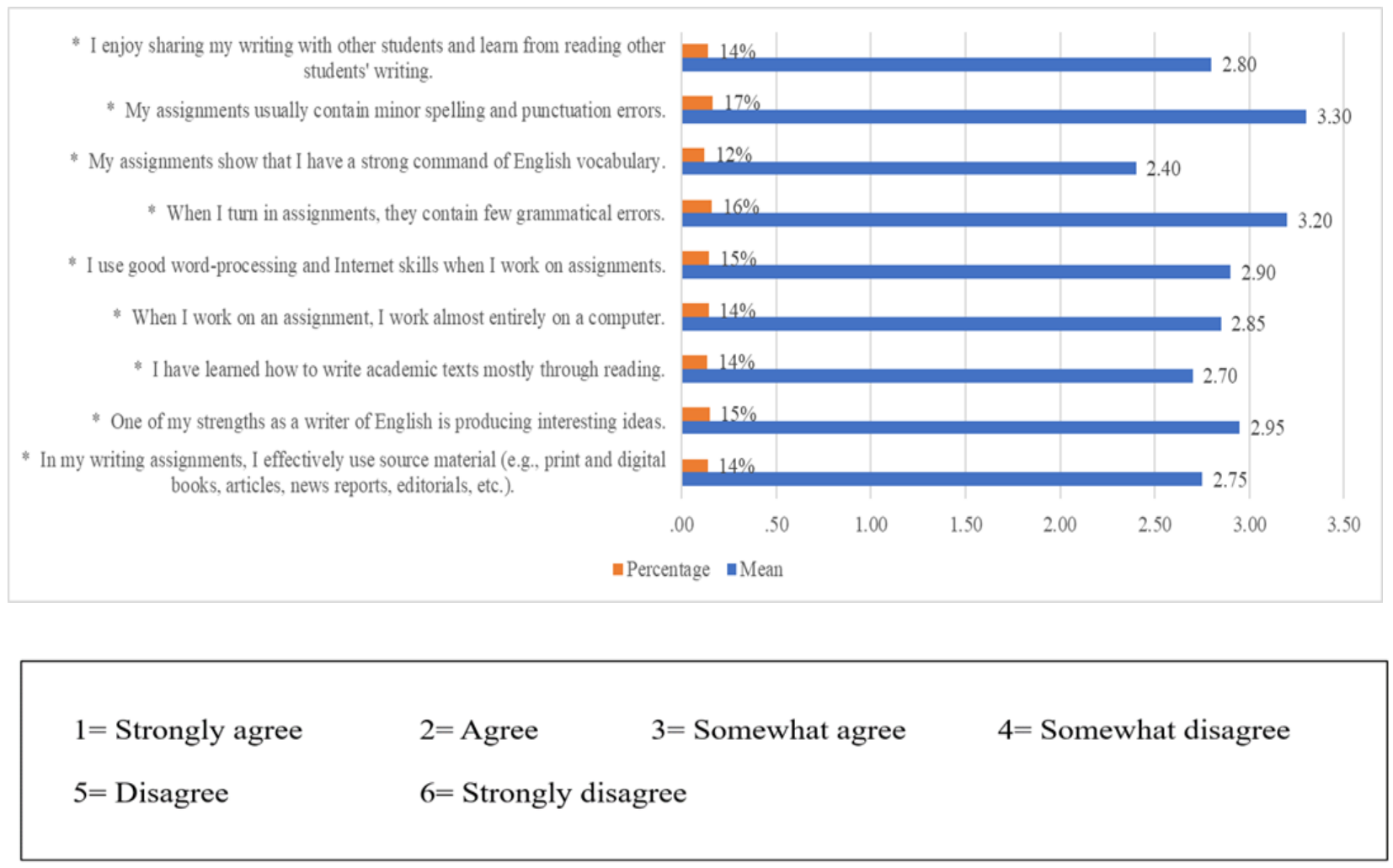

Figure 2. Group 1 Responses on the Preferences Survey

The responses of Group 1 are described in Figure 2 above. It can be seen that $17 \%$ of the learners of this group reported that they somewhat agree that their assignments contain minor mechanic errors. The graph shows that $16 \%$ of the learners reported a gradual drop in their grammatical errors. In terms of generating ideas, $15 \%$ of the learners' responses reveal that they somewhat agree that they can produce interesting ideas. Figure 2 reveals that 14 to $15 \%$ of the learners somewhat use the computer and internet skills in their writing tasks. In terms of collaborative writing, $14 \%$ of the learners reported that they somewhat agree on sharing their writing with their colleagues and learning from reading each other's texts. The graph shows that $14 \%$ of the learners use extra source material in their writing tasks. The figure also reveals that $14 \%$ of the learners learned writing through reading. By looking at the graph, it is interpreted that $12 \%$ of the learners agree on their ability to use strong vocabulary in their writing tasks. 


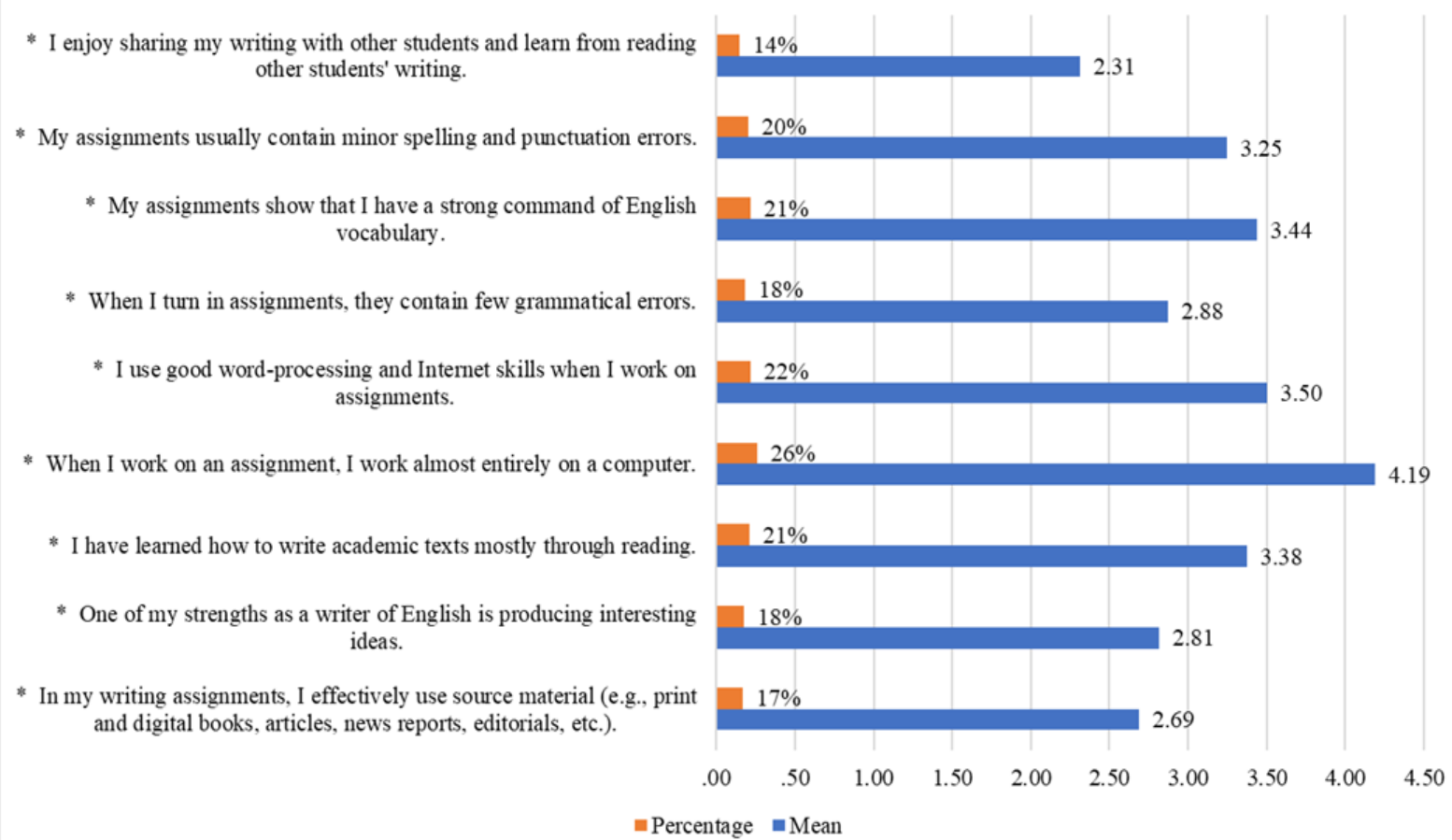

\begin{tabular}{ll|}
$\begin{array}{l}1=\text { Strongly agree } \\
5=\text { Disagree }\end{array}$ & $6=$ Agree $\quad 3=$ Somewhat agree $\quad 4=$ Somewhat disagree \\
\end{tabular}

Figure 3. Group 2 Responses on the Preferences Survey

The responses of Group 2 are described in Figure 3 above. The chart shows that $26 \%$ of the learners somewhat disagree on using the computer when they write their assignments. Also, $22 \%$ of the learners reported that they somewhat agree on using the internet when they write their assignments. In terms of the reading-writing connection, $21 \%$ of the learners somewhat agree that they have learned writing mostly from reading. $21 \%$ of the learners somewhat agree that they use strong English vocabulary in their writing. The chart shows that $20 \%$ of the learners somewhat agree that their writing assignments contain mechanical errors. Regarding grammatical errors, $18 \%$ of the learners reported that their assignments contain few grammatical errors. The figure also shows that $18 \%$ of the learners somewhat agree on that they can produce exciting ideas. $17 \%$ of the learners reported that they somewhat use extra source material in their writing assignments. The figure also reveals that $14 \%$ of the learners agree on collaborative writing. 


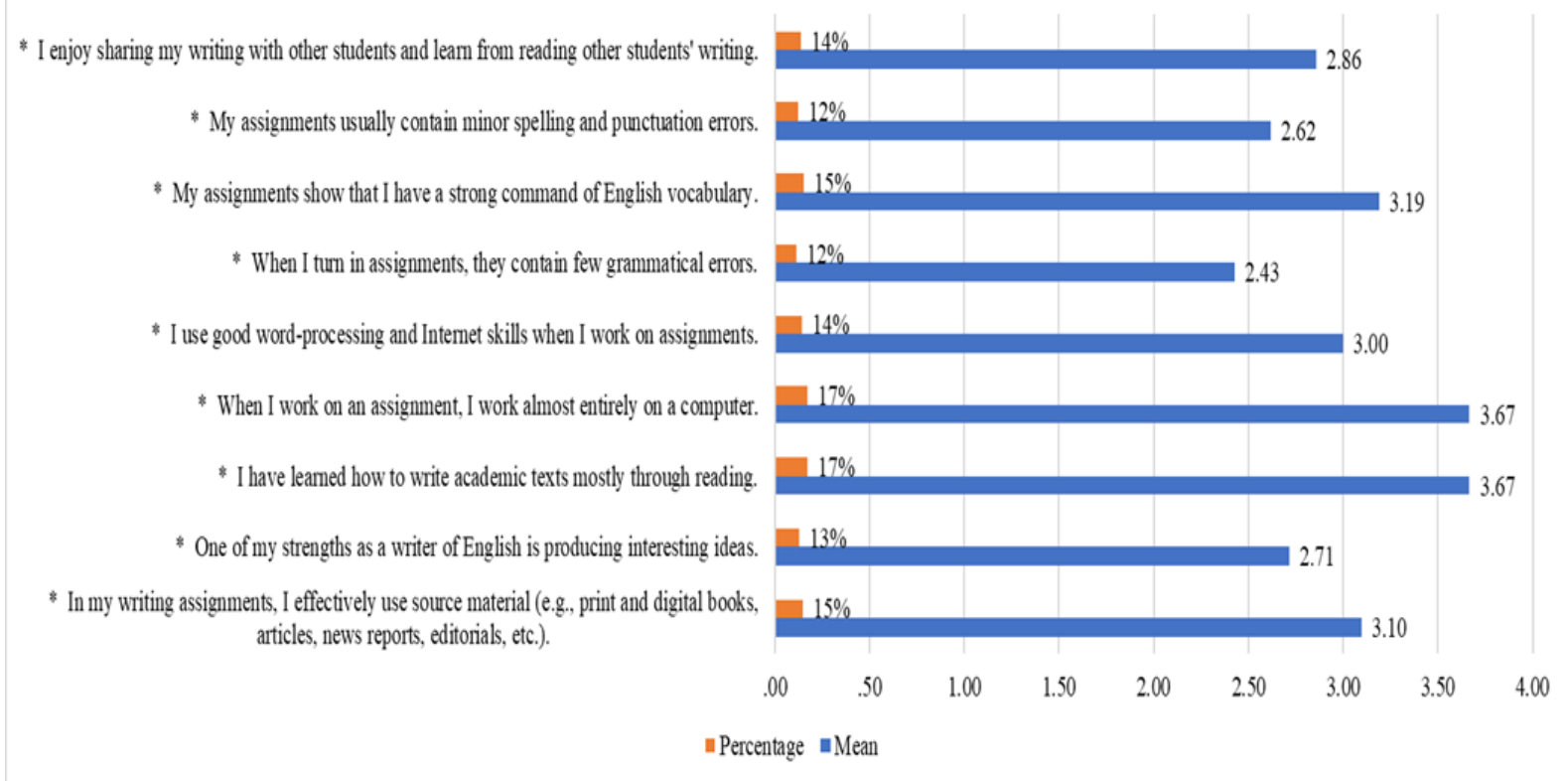

$$
\begin{array}{ll}
1=\text { Strongly agree } & 2=\text { Agree } \quad 3=\text { Somewhat agree } \quad 4=\text { Somewhat disagree } \\
5=\text { Disagree } & 6=\text { Strongly disagree }
\end{array}
$$

Figure 4. Group 3 Responses on the Preferences Survey

The responses of Group 3 are described in Figure 4 above. The chart shows that $17 \%$ of the learners somewhat disagree on the reading-writing connection. They also somewhat disagree on using the computer in their writing assignments. The figure reveals that $15 \%$ of the learners somewhat agree on their ability to use strong vocabulary and rely on extra source material in writing assignments. Furthermore, $14 \%$ of the learners somewhat agree that they use the internet and software whenever they work on writing assignments. Figure 4 also reveals that $14 \%$ of the learners somewhat agree on collaborative writing. In terms of generating ideas, $13 \%$ of the learners reported that they somewhat agree on their ability to produce new ideas. $12 \%$ of the learners somewhat agree on having minor mechanical and grammatical errors in writing assignments. 


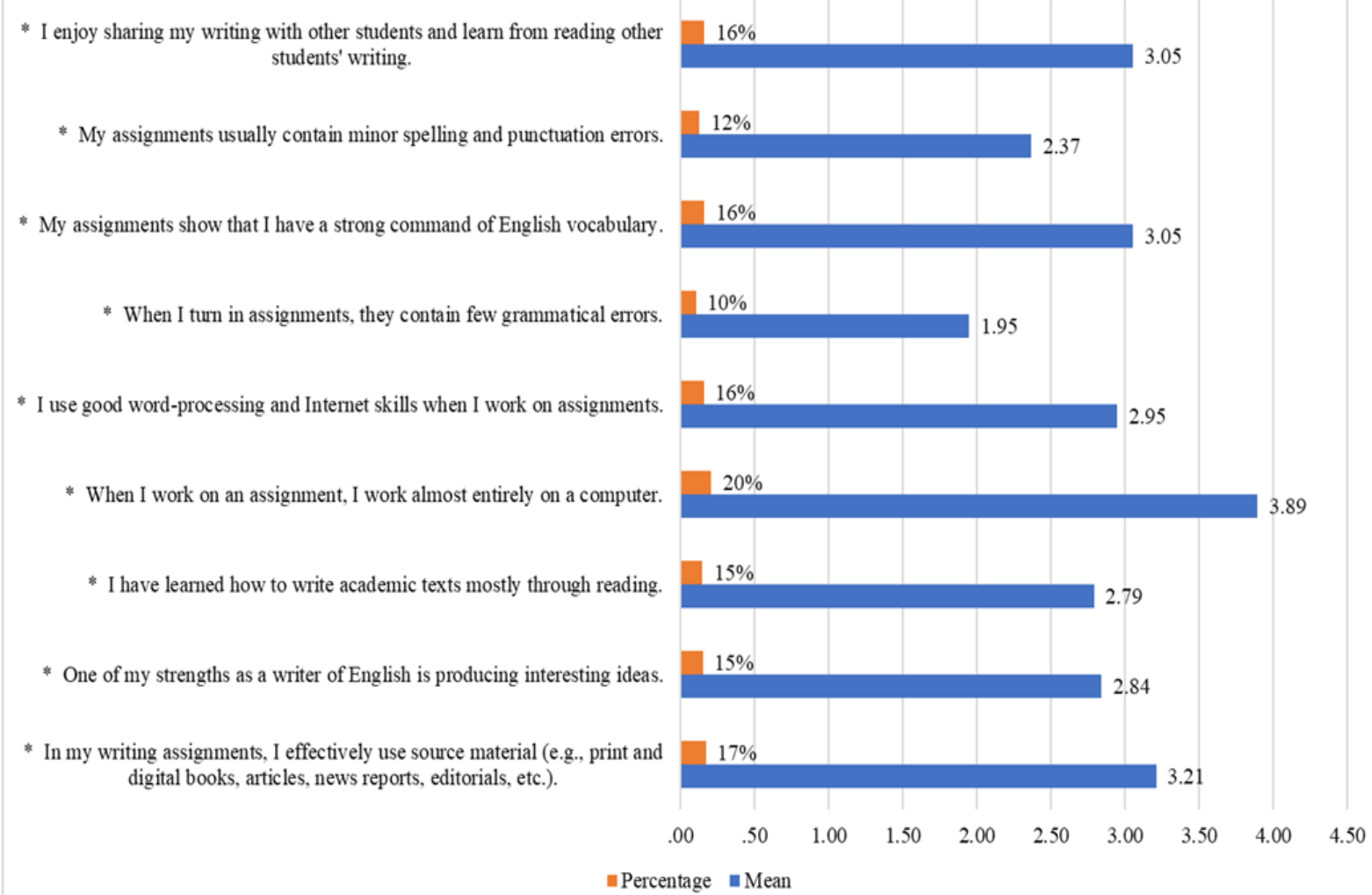

- Percentage $=$ Mean

$\begin{array}{ll}1=\text { Strongly agree } & 2=\text { Agree } \quad 3=\text { Somewhat agree } \quad 4=\text { Somewhat disagree } \\ 5=\text { Disagree } & 6=\text { Strongly disagree }\end{array}$

Figure 5. Group 4 Responses on the Preferences Survey

The responses of Group 4 are described in Figure 5 above. The chart reveals that $20 \%$ of the learners somewhat disagree on working almost entirely on the computer in their writing assignments. However, $17 \%$ of them somewhat agree on their effectiveness in using source materials other than course books. The chart also shows that $16 \%$ of the learners somewhat agree on their ability for using strong vocabulary in their writing assignments, and their enjoyment of collaborative writing. Likewise, the chart reveals that $16 \%$ of the learners somewhat agree on using internet skills in their writing assignments. Moreover, $15 \%$ of the learners reported that they believe in the reading-writing connection to produce novel ideas. The chart shows that $12 \%$ of the learners agree that their assignments contain minor spelling and punctuation errors, while $10 \%$ of them agree that they have few grammatical errors. 


\section{Discussion}

\subsection{What Writing Genre do L2 Novice Writers Prefer?}

Self-awareness of L2 writing needs is a significant knowledge for both teachers and learners before doing a task (Chandler, 2003; Ferris \& Hedgcock, 2014; Ferris, 2011; Leijten, Waes, \& Ransdell, 2010; Zhang \& Zhang, 2018). As a result, the preferences surveys were distributed to the learners in order to get the learners aware of their preferences in writing on one hand, and their strength points on the other. The leading indicator of genre preferences in the present study is found in the last question of the preferences survey "What writing genre do you prefer?".

The main findings that can be interpreted from the preferred genre question were that $40 \%$ of Group 1 and $43.8 \%$ of Group 2 selected the narrative genre to be the best for them in the writing tasks. Moreover, 33.3\% of Group 3 and 36.8 of Group 4 selected the opinion genre to be the best for them in the writing tasks. Group 4 also reported that $36.8 \%$ of them preferred the narrative genre in the writing tasks.

The high redundancy in selecting the narrative genre was noticed in the results of the preferences survey. The narrative genre is known for its descriptive language, which creates pictures in the mind and the writing tool colors it with real or imaginary scenes and events (Olson et al., 2018). As Olson et al. asserts, narration is a highly motivating genre that opens the gates for learners to use both communicative and linguistic knowledge. This was proven by participants of the present study who succeeded in showing their linguistic competence in grammar and lexico-grammatical knowledge.

\subsection{Were Those Writers Aware of the Strength Points and the Weakness Points of Themselves?}

The preferences surveys that were distributed to Groups (1,2,3, and 4) determined learners' awareness of their errors in writing. The main findings of the preferences surveys, particularly regarding the learners' self-awareness of their errors in writing were many. First, $17 \%$ of Group 1 reported that they moderately agree that their writing texts contain few mechanics errors, whereas $12 \%$ of Group 2 reported they have few mechanics errors. Regarding Groups 3 and 4, 20\% of Group 3 moderately agree that their texts contain mechanics errors, whereas $12 \%$ of Group 4 reported that their texts contain mechanics errors. This means that they were aware of their mechanics' errors.

Regarding awareness of grammatical errors, the main findings indicated that $16 \%$ of Group 1 reported that they moderately agree that their texts contain few grammatical errors, whereas $12 \%$ of Group 2 have minor grammatical errors. $18 \%$ of the Group 3 moderately agree that their texts contain few grammatical errors, whereas $10 \%$ of the Group 4 agree on the same point. These findings indicated that the learners were aware of their grammatical errors. Referring to Wetzorke (2005), the participants were aware of their mechanics and grammatical mistakes and slips, and in this case, only in their writing performance, not competence. 


\section{Conclusion}

Thus far, this paper has answered the two research questions, namely: "What writing genre do L2 novice writers prefer?", and "Were those writers aware of the strength points and the weakness points of themselves?". Both of the research questions were answered by the preferences survey of novice EFL writers. The results can be summarized as follows:

1. The learners were aware of their mechanic errors in writing

2. They were aware of their grammatical errors

3. They were aware of the importance of vocabulary use in their writing

4. Most of the learners were aware of the reading-writing connection, genre, and lexico-grammar

In summary, the UBT learners were aware of their abilities as novice writers, but still in need of increasing their literacy skills by adapting context-relevant teaching methods that encourage them to write freely without anxiety. The Saudi learners do not only need to be given feedback, but they also need to be self-regulated of themselves as EFL writers. This can be encouraged by using preferences surveys before starting the writing courses. Since the advent new technology, Saudi learners had to tackle the different writing genres with different tools of learning, mainly, computer-based typing alongside paper-based writing.

Teachers should encourage reading before writing tasks, and develop writing assessment through reading-based tasks. It is recommended to conduct more research on using writing preferences surveys before the writing courses to help the L2 learners being self-regulated about their strength points from one hand, and their weakness points from the other hand. It is also important for future research to supply the learners' responses on preferences surveys with interviews to get more insights on writing preferences, styles, and self-regulation. The English institutions have to include writing mandatory workshops once a week in the teaching syllabus, and to select context-relevant topics for writing that fit learners' preferences and needs. Also, they have to encourage higher order thinking in writing through collaboration and autonomy.

\section{Acknowledgement}

This article is acknowledged to the English Language Academy (ELA) at the University of Business and Technology (UBT).

\section{References}

Ahmed, S., \& Han, Z. (2018). Models of Reading. In John I. Liontas (Ed.), (Project Editor: Margo DelliCarpini; Volume Editors: Niel J Anderson, Diane D. Belcher, and Alan Hirvela), The TESOL Encyclopedia of English Language Teaching (Vol. 4, pp. 2153-2159). Hoboken, USA: John Wiley \& Sons, Inc. 
Alsagoff, L. (2018). Describing Proficiency. In John I. Liontas (Ed.), (Project Editor: Margo DelliCarpini; Volume Editor: Shahid Abrar-ul-Hassan), The TESOL Encyclopedia of English Language Teaching (Vol. 1, pp. 87-99). Hoboken, USA: John Wiley \& Sons, Inc.

Anderson, N. J. (2018). Silent Reading Fluency. In John I. Liontas (Ed.), (Project Editor: Margo DelliCarpini; Volume Editors: Niel J Anderson, Diane D. Belcher, and Alan Hirvela), The TESOL Encyclopedia of English Language Teaching (Vol. 4, pp. 2212-2221). Hoboken, USA: John Wiley \& Sons, Inc.

Bui, G., \& Skehan, P. (2018) Complexity, Accuracy, and Fluency. In John I. Liontas (Ed.), (Project Editor: Margo DelliCarpini; Volume Editors: Hossein Nassaji and Kate Mastruserio Reynolds), The TESOL Encyclopedia of English Language Teaching (Vol. 5, pp. 2645-2652). Hoboken, USA: John Wiley \& Sons, Inc.

Chandler, J. (2003). The efficacy of various kinds of error feedback for improvement in the accuracy and fluency of L2 student writing. Journal of Second Language Writing, 12, 267-296. http://doi.org/10.1016/S1060-3743(03)00038-9

Coxhead, A. (2018). Vocabulary and Second Language Writing. In John I. Liontas (Ed.), (Project Editor: Margo DelliCarpini; Volume Editors: Niel J Anderson, Diane D. Belcher, and Alan Hirvela), The TESOL Encyclopedia of English Language Teaching (Vol. 4, pp. 2597-2602). Hoboken, USA: John Wiley \& Sons, Inc.

Crossley, S. A. (2018). Authentic and Simplified Texts. In John I. Liontas (Ed.), (Project Editor: Margo DelliCarpini; Volume Editors: Niel J Anderson, Diane D. Belcher, and Alan Hirvela), The TESOL Encyclopedia of English Language Teaching (Vol. 4, pp. 2028-2034). Hoboken, USA: John Wiley \& Sons, Inc.

David, N., \& De Hoyos, D. (2018). Advanced-Level Readers. In John I. Liontas (Ed.), (Project Editor: Margo DelliCarpini; Volume Editors: Niel J Anderson, Diane D. Belcher, and Alan Hirvela), The TESOL Encyclopedia of English Language Teaching (Vol. 4, pp. 2022-2028). Hoboken, USA: John Wiley \& Sons, Inc.

David, N., \& McGovern, J. (2018). Beginning-Level Readers. In John I. Liontas (Ed.), (Project Editor: Margo DelliCarpini; Volume Editors: Niel J Anderson, Diane D. Belcher, and Alan Hirvela), The TESOL Encyclopedia of English Language Teaching (Vol. 4, pp. 2041-2046). Hoboken, USA: John Wiley \& Sons, Inc.

Doolan, S. M. (2017). Comparing Patterns of Error in Generation 1.5, L1, and L2 First-Year Composition Writing. Journal of Second Language Writing, 35, 1-17. http://doi.org/10.1016/j.jslw.2016.11.002

Erten, I. H. (2018). Role of Vocabulary in Teaching Reading. In John I. Liontas (Ed.), (Project Editor: Margo DelliCarpini; Volume Editors: Niel J Anderson, Diane D. Belcher, and Alan Hirvela), The TESOL Encyclopedia of English Language Teaching (Vol. 4, pp. 2201-2206). Hoboken, USA: John Wiley \& Sons, Inc. 
Ferris, D. R. (2011). Treatment of Error in Second Language Student Writing (2nd ed.). (D. Belcher, \& J. Liu, Eds.) Michigan: The University of Michigan Press.

Ferris, D. R., \& Hedgcock, J. S. (2014). Teaching L2 Composition Purpose, Process, and Practice (3rd ed.). New York: Routledge.

Gebril, A. (2018). Integrated-Skills Assessment. In John I. Liontas (Ed.), (Project Editor: Margo DelliCarpini; Volume Editors: Niel J Anderson, Diane D. Belcher, and Alan Hirvela), The TESOL Encyclopedia of English Language Teaching (Vol. 4, pp. 2383-2389). Hoboken, USA: John Wiley \& Sons, Inc.

Grabe, W., \& Jiang, X. (2018). First Language and Second Language Reading. In John I. Liontas (Ed.), (Project Editor: Margo DelliCarpini; Volume Editors: Niel J Anderson, Diane D. Belcher, and Alan Hirvela), The TESOL Encyclopedia of English Language Teaching (Vol. 4, pp. 2097-2103). Hoboken, USA: John Wiley \& Sons, Inc.

Hernandez, T. A. (2018). Input Flooding. In John I. Liontas (Ed.), (Project Editor: Margo DelliCarpini; Volume Editors: Hossein Nassaji and Kate Mastruserio Reynolds), The TESOL Encyclopedia of English Language Teaching (Vol. 5, pp. 2794-2799). Hoboken, USA: John Wiley \& Sons, Inc.

Hirvela, A. (2004). Connecting Reading \& Writing in Second Language Writing Instruction. In D. Belcher, \& J. Liu (Eds.). Michigan: The University of Michigan Press.

Huang, H.-c. (2014). Online Versus Paper-based Instruction: Comparing Two Strategy Training Modules for Improving Reading Comprehension. RELC Journal, 45(2), 165-180. http://doi.org/10.1177/0033688214534797

Hughes, A. (2003). Testing for Language Teachers (2nd ed.). Cambridge: Cambridge University Press.

Hyland, K. (2004). Genre and Second Language Writing. Michigan: The University of Michigan Press.

Hyland, K. (2018). Genre and Second Language Writing. In John I. Liontas (Ed.), (Project Editor: Margo DelliCarpini; Volume Editors: Niel J Anderson, Diane D. Belcher, and Alan Hirvela), The TESOL Encyclopedia of English Language Teaching (Vol. 4, pp. 2359-2364). Hoboken, USA: John Wiley \& Sons, Inc.

Hymes, D. (1966). On communicative competence. The Research Planning Conference on language development among disadvantaged children. Yeshiva: Yeshiva.

Janopoulos, M. (1992). University Faculty Tolerance of NS and NNS Writing Errors: A Comparison. Journal of Second Language Writing, 1(2), 109-121.

Kormos, J. (2012). The role of individual differences in L2 writing. Journal of Second Language Writing, 21, 390-403. http://dx.doi.org/10.1016/j.jslw.2012.09.003

Krashen, S. (1984). Writing: Research, theory, and applications. Oxford, UK: Pergamon. 


\section{$\triangle$ Macrothink}

International Journal of Education ISSN 1948-5476

Lee, J. F. (2018). Comprehensible Input. In John I. Liontas (Ed.), (Project Editor: Margo DelliCarpini; Volume Editors: Hossein Nassaji and Kate Mastruserio Reynolds), The TESOL Encyclopedia of English Language Teaching (Vol. 5, pp. 2652-2658). Hoboken, USA: John Wiley \& Sons, Inc.

Lee, J., \& Schallert, D. L. (2015). Exploring the Reading-Writing Connection: A Yearlong Classroom-Based Computer-based Study of Middle School Students Developing Literacy in a New Language. Reading Research Quarterly, 51(2), 143-164. http://doi.org/10.1002/rrq.132

Leijten, M., Waes, L. V., \& Ransdell, S. (2010). Correcting Text Production Errors: Isolating the Effects of Writing Mode from Error Span, Input Mode, and Lexicality. Written Communication, 27(2), 189-227. http://doi.org/10.1177/0741088309359139

Leow, R. P. (2018). Noticing Hypothesis. In John I. Liontas (Ed.), (Project Editor: Margo DelliCarpini; Volume Editors: Hossein Nassaji and Kate Mastruserio Reynolds), The TESOL Encyclopedia of English Language Teaching (Vol. 5, pp. 2884-2890). Hoboken, USA: John Wiley \& Sons, Inc.

Li, G., \& Zhou, W. (2018). Authentic Materials", in John I. Liontas (Ed.), (Project Editor: Margo DelliCarpini; Volume Editor: Shahid Abrar-ul-Hassan), The TESOL Encyclopedia of English Language Teaching (Vol. 1, pp. 30-43). Hoboken, USA: John Wiley \& Sons, Inc.

Mokhtari, K. (2018) Prior Knowledge Fuels the Development of Reading Comprehension Strategies. In John I. Liontas (Ed.), (Project Editor: Margo DelliCarpini; Volume Editors: Niel J Anderson, Diane D. Belcher, and Alan Hirvela), The TESOL Encyclopedia of English Language Teaching (Vol. 4, pp. 2181-2190). Hoboken, USA: John Wiley \& Sons, Inc.

Nation, I. S. (2001). Learning vocabulary in another language. Cambridge, England: Cambridge University Press.

Olson, C. B., Scarcella, R., \& Matuchniak, T. (2018). Task Development: Narrative, Expository, and Argumentative Writing. In John I. Liontas (Ed.), (Project Editor: Margo DelliCarpini; Volume Editors: Niel J Anderson, Diane D. Belcher, and Alan Hirvela), The TESOL Encyclopedia of English Language Teaching (Vol. 4, pp. 2530-2536). Hoboken, USA: John Wiley \& Sons, Inc.

Patten, B. V., \& Benati, A. G. (2010). Key Terms in Second Language Acquisition. London: Continuum International Publishing Group.

Qu, W. (2017). For L2 writers, it is always the problem of the language. Journal of Second Language Writing, 38, 92-93. http://doi.org/10.1016/j.jslw.2017.10.007

Recinos, M. L. (2018). Building a Culture of Reading. In John I. Liontas (Ed.), (Project Editor: Margo DelliCarpini; Volume Editors: Niel J Anderson, Diane D. Belcher, and Alan Hirvela), The TESOL Encyclopedia of English Language Teaching (Vol. 4, pp. 
2047-2052). Hoboken, USA: John Wiley \& Sons, Inc.

Ruschoff, B. (2018). Authentic Language Use. In John I. Liontas (Ed.), (Project Editor: Margo DelliCarpini; Volume Editors: Ali Fuad Selvi and Ali Shehadeh), The TESOL Encyclopedia of English Language Teaching (Vol. 2, pp. 503-509). Hoboken, USA: John Wiley \& Sons, Inc.

Taylor, S. K., Despagne, C., \& Faez, F. (2018). Critical Language Awareness. In John I. Liontas (Ed.), (Project Editor: Margo DelliCarpini; Volume Editor: Shahid Abrar-ul-Hassan), The TESOL Encyclopedia of English Language Teaching (Vol. 1, pp. 73-85). Hoboken, USA: John Wiley \& Sons, Inc.

Tseng, T. J. (2009). Theoretical Perspectives on Learning a Second Language. In Heinemann, S. Bruce, \& B. Rafoth (Eds.), ESL Writers A Guide for Writing Center Tutors (2nd ed.), pp. 18-32). Portsmouth, NH: Boynton/Cook Publishers, Inc.

Valeo, A. (2018). Isolated Versus Integrated Form-Focused Instruction. In John I. Liontas (Ed.), (Project Editor: Margo DelliCarpini; Volume Editors: Hossein Nassaji and Kate Mastruserio Reynolds), The TESOL Encyclopedia of English Language Teaching (Vol. 5, pp. 2832-2836). Hoboken, USA: John Wiley \& Sons, Inc.

Vygotsky, L. S. (1978). Mind in Society: The Development of Higher Psychological Processes. Cambridge: Harvard University Press.

Warschauer, M. (1997). Computer-Mediated Collaborative Learning: Theory and Practice. The Modern Language Journal, 81(4), 470-481. http://doi.org/10.1111/j.15404781.1997.tb05514.x

Wetzorke, R. (2005). An Introduction to the Concept of Error Analysis. Norderstedt: GRIN Verlag.

Zaid, M. (2011). Effectiveness of Organised E-mail Exchanges and Online Reading/Writing on College Students' Literacy Development and their Attitudes towards English: A Study from Saudi Arabia. (P. Robertson, \& R. Nunn, Eds.) Asian EFL Journal, 13(1), 10-47.

Zhang, L. (2018). Reading and Writing Connections. In John I. Liontas (Ed.), (Project Editor: Margo DelliCarpini; Volume Editors: Niel J Anderson, Diane D. Belcher, and Alan Hirvela), The TESOL Encyclopedia of English Language Teaching (Vol. 4, pp. 2191-2195). Hoboken, USA: John Wiley \& Sons, Inc.

Zhang, L. J., \& Zhang, D. (2018). Metacognition in TESOL: Theory and Practice. In John I. Liontas (Ed.), (Project Editor: Margo DelliCarpini; Volume Editors: Ali Fuad Selvi and Ali Shehadeh), The TESOL Encyclopedia of English Language Teaching (Vol. 2, pp. 682-689). Hoboken, USA: John Wiley \& Sons, Inc.

Zimmermann, R. (1999). L2 writing: subprocesses, a model of formulating and empirical findings. Learning and Instruction, 10(2000), 73-99. http://doi.org/10.1016/S09594752(99)00019-5 


\section{Appendix}

Appendix 1. Survey of strength, styles, and preferences

This portion of the survey is designed to help you and your instructor understand how you prefer to plan and complete writing assignments in English. Think about your most recent experiences in classes where you wrote academic papers. For each statement, check the numeric value that best describes your habits and preferences. Again, be honest!

$$
\begin{aligned}
& 1=\text { Strongly agree } \quad 3=\text { Somewhat agree } \quad 5=\text { Disagree } \\
& 2=\text { Agree } \quad 4=\text { Somewhat disagree } \quad 6=\text { Strongly disagree }
\end{aligned}
$$

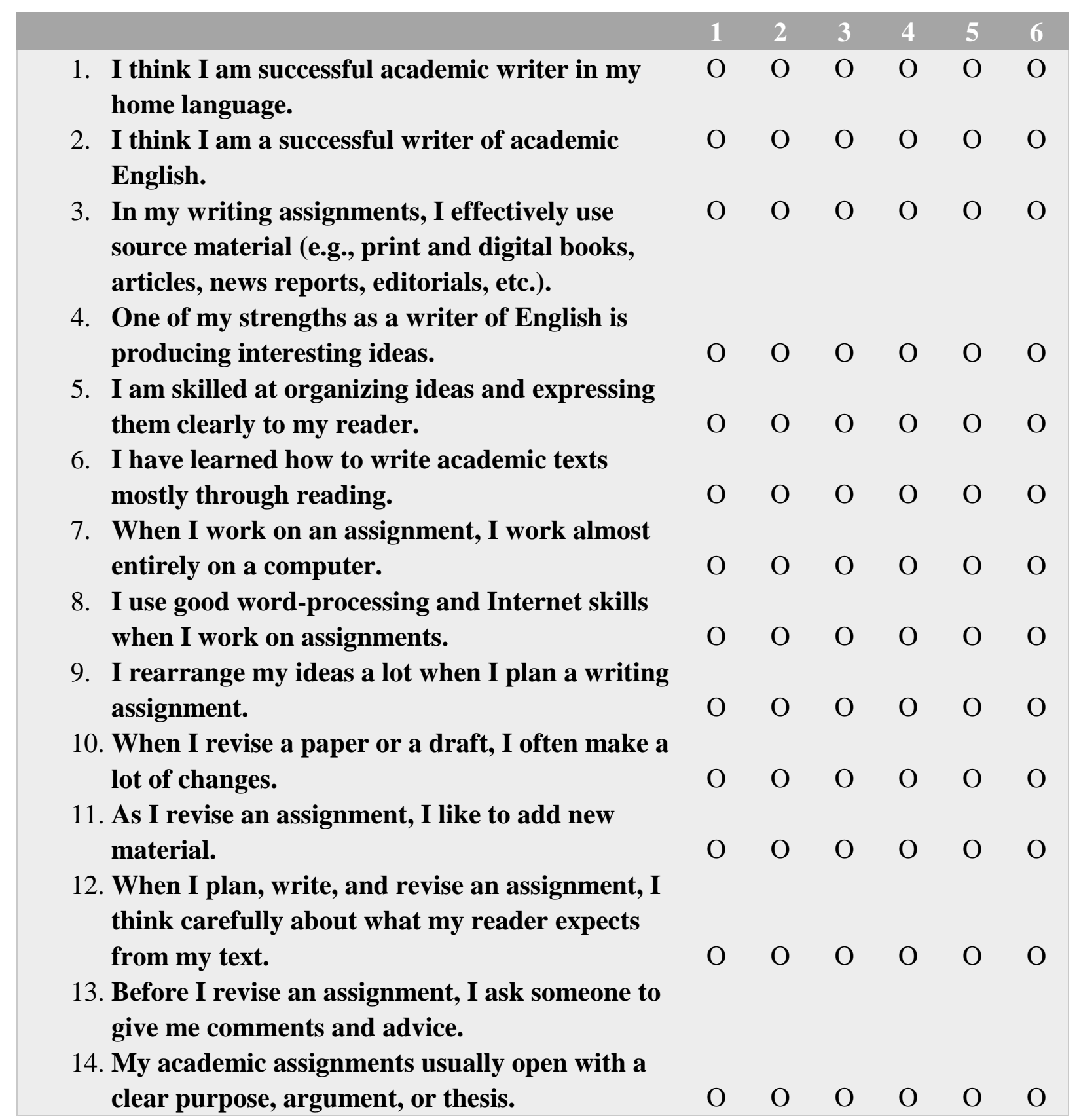




\section{Macrothink}

15. In my academic assignments, I try to include examples and sources to support my points.

16. I try to connect paragraphs to my main ideas or arguments in my academic assignments.

17. When I turn in assignments, they contain few grammatical errors.

18. My assignments show that I have a strong command of English vocabulary.

19. My assignments usually contain minor spelling and punctuation errors.

20. I am confident about using references, quotations, and footnotes in my assignments.

21. I know how to organize and format a bibliography or list of references.

22. I learn a lot from the comments and corrections that my instructors write on my assignments.

23. I enjoy sharing my writing with other students and learn from reading other students' writing.

24. After getting instructor feedback on my writing, I learn things that I can apply to future writing tasks.

25. I prefer to interact with my instructor and get feedback digitally, rather than on paper or in person.

$\begin{array}{llllll}\mathrm{O} & \mathrm{O} & \mathrm{O} & \mathrm{O} & \mathrm{O} & \mathrm{O}\end{array}$

$\begin{array}{llllll}\mathrm{O} & \mathrm{O} & \mathrm{O} & \mathrm{O} & \mathrm{O} & \mathrm{O}\end{array}$

$\begin{array}{llllll}\mathrm{O} & \mathrm{O} & \mathrm{O} & \mathrm{O} & \mathrm{O} & \mathrm{O}\end{array}$

What genre do you prefer to write?

(Adopted from Ferris \& Hedgcock, 2014, p. 185)

\section{Copyright Disclaimer}

Copyright for this article is retained by the author(s), with first publication rights granted to the journal.

This is an open-access article distributed under the terms and conditions of the Creative Commons Attribution license (http://creativecommons.org/licenses/by/3.0/). 